\title{
Harvesting Time Influences Bruising Susceptibility, Quality and Storagability of Swilling Peach Fruits
}

\author{
Nermeen I. EL- Naggar ${ }^{1}$ and Ragaa M. El-Saedy ${ }^{2}$
}

\begin{abstract}
The present study was carried out during 2006 and 2007 seasons on Swilling peach fruits. Five harvests were performed at two days intervals during the commercial harvesting season. During each harvest, bruised fruits percentage, the number and the diameter of the bruised areas were determined. Sound selected fruits of each harvest were stored at $0^{\circ} \mathrm{C}$. There was a significant increase in the bruised fruits percentages during the harvesting two seasons correlated with the increase in the number of bruised area per each fruit. This number increased at the third harvest then declined which may be due to the attachment of the bruised areas where the diameter of those bruised area increase significantly with the progress of the harvesting season. The $50 \mathrm{~cm}$ height was the most effective one on the sound fruit susceptibility to bruising. It caused clear bruised areas and watery symptoms appeared on the peel and flesh with faster changes to brown color at RT. In both seasons, the first and second harvests of peach fruits had the significantly highest weight loss during the storage period. Flesh firmness decreased significantly at the last harvests. Fruits of all the harvests lost its flesh firmness with the advancing of the storage period. At harvest time and during cold storage, the fruits of the earlier harvests had the significant lowest SSC values. The later harvest time the lowest acidity and total phenols and the highest water soluble pectin percentages. Peach fruits must be picked, packed and transported gently to avoid bruising and marketed, then consumed within three weeks to avoid mealiness or firmness loss.
\end{abstract}

\section{INTRODUCTION}

Appearance and texture of fruit are the two most important quality features used by the consumers to choose peaches (Gutierrez et al. 2007). So, peach fruits have to be treated carefully during picking, sorting, packing and storage processes to maintain quality and avoid damage specially bruising that affects not only the fruit ' cosmetic appearance but restricted to higher risk of bacterial and fungal contamination, leading to a lower shelf-life and causes considerable losses to peach industry (Crisosto et al., 1993 and Zeebroeck et al., 2007).

Bruising usually caused by mechanical impacts with hard surfaces or other fruits and defined as external damage and flesh discoloration (Labavitch et

\footnotetext{
${ }^{1}$ Dep.Plant. Prod.(Pomology), Institute of Efficient Productivity,

Zag. Unv.

2Maamoura Botanical Garden , Alex.Hort. Res., Agric.

Res. Center, Giza Egypt.

Received October27, 2008, Accepted December 30, 2008
}

al., 1998). The amount of impact or compression damage is usually described in terms of external (diameter and area) or internal (depth and volume) bruise size attributes (Bollen, 2002).

Firmness not only might be a reasonable estimation of maturity, but it is also related with shelf-life because the firmness of a fruit decreases gradually as it becomes more mature and rapidly as it ripens. This perception is also employed to estimate if the fruit has undergone any kind of physical damage (Gutierrez et al., 2007 and Guerra and Casquero, 2008).

In peach the time of harvest influences changes in organic acids, development of volatile and aromatic substances, fruit softening, increases in nutritional and healthful compounds. All the above changes determine fruit quality and fruits are usually harvested well before physiological ripening with high flesh firmness to ensure maximum resistance to bruising and long storage and shelf-life (Remorini et al., 2008).

The aim of the current work was to study the bruising and firmness characteristics of Swilling peach fruits and its changes with harvest time. Also, study the bruising susceptibility and the cold storage potential of full sound peach fruits in response to the different harvest times and the effect of these times on the physical (weight loss and firmness) and the chemical (SSC, titratable acidity, flesh total phenols and flesh pectin content) properties changes during cold storage.

\section{MATERIALS AND METHODS}

The present study was carried out during 2006 and 2007 seasons on Swilling peach fruits harvested from a private orchard in El-Nobaria, Alexandria. Five harvests were performed at two days intervals during the commercial harvesting season. During each harvest, more than 500 peach fruits were sorted to sound and bruised ones to determine the bruising percentage in each harvest, then the bruised fruits were sorted to determine the number and the diameter of the bruised areas. Sound selected fruits of each harvest were transported to the Postharvest Center of Horticulture Crops, Faculty of Agriculture, Alexandria University. 
Bruising susceptibility of sound fruits was carried out by dropping the fruits (10 replicates) from different heights of $20,30,40$ and $50 \mathrm{~cm}$ through hard plastic cylinders have the above heights with $12 \mathrm{~cm}$ diameter onto a flat, smooth and rigid wooden surface. To mark the impact area on the fruit, the surface was covered with a thin layer of talcum powder. After testing, the fruits were individually placed in the lab to visually evaluate the impact injury symptoms of the fruit skin and flesh after 0, 2, 4, 6 and 24 hours.

The initial fruit quality (average of 15 fruits of each harvest) was determined (table 1) then the fruits were stored at $0^{\circ} \mathrm{C}$ with $85-90 \%$ relative humidity. The physio-chemical properties of the stored fruits were followed up in 4 days intervals throughout the storage period as follow.

15 fruits of each harvest were labeled then weighed to calculate fruit weight loss percent during the storage period in relation to its original weight.

Patches of skin were peeled from two opposite sides of each given fruit in the sample to measure the flesh firmness by using the Effegi pressure tester with an eight mm plunger (Effegi, 48011 Alfonsine, Italy).

Two opposite segments from the rose to the stem end of each fruit were taken and each of them was squeezed and the obtained juice was used to determine the percentage of the soluble solids content (SSC) by the use of a hand refractometer (Chen and Mellenthin, 1981).

Table 1. The Initial Quality of Five Harvests of Swilling Peach Fruits during 2006 and 2007 Seasons

\begin{tabular}{|c|c|c|c|c|c|c|c|c|c|c|}
\hline \multirow{3}{*}{ Parameter } & \multicolumn{10}{|c|}{ Harvest Time } \\
\hline & \multicolumn{2}{|c|}{1} & \multicolumn{2}{|c|}{2} & \multicolumn{2}{|c|}{3} & \multicolumn{2}{|c|}{4} & \multicolumn{2}{|c|}{5} \\
\hline & 2006 & 2007 & 2006 & 2007 & 2006 & 2007 & 2006 & 2007 & 2006 & 2007 \\
\hline Weight (gm) & 96.22 & 94.03 & 92.30 & 88.90 & 84.20 & 79.96 & 87.70 & 86.00 & 84.60 & 85.74 \\
\hline $\begin{array}{l}\text { Size : } \\
\text { Length }(\mathrm{cm})\end{array}$ & 5.14 & 4.51 & 3.68 & 3.54 & 3.54 & 3.42 & 3.64 & 360 & 364 & 376 \\
\hline Diameter $(\mathrm{cm})$ & 5.62 & 5.01 & 4.04 & 3.94 & 3.70 & 3.78 & 3.72 & 3.76 & 3.78 & 3.74 \\
\hline $\begin{array}{l}\text { Firmness } \\
\left(\mathrm{lb} / \mathrm{in}^{2}\right)\end{array}$ & 11.20 & 11.34 & 11.76 & 11.48 & 10.10 & 10.48 & 9.82 & 9.96 & 9.28 & 8.90 \\
\hline $\operatorname{SSC}(\%)$ & 10.64 & 12.56 & 12.20 & 12.80 & 12.76 & 12.32 & 13.64 & 14.48 & 15.28 & 14.56 \\
\hline Acidity (\%) & 0.37 & 0.32 & 0.32 & 0.31 & 0.27 & 0.30 & 0.30 & 0.31 & 0.24 & 0.25 \\
\hline
\end{tabular}

Table 2. Percentage, Number per Fruit and Diameter of the Bruising Areas of Harvested Swilling Peach Fruits during 2006 and 2007 Seasons

\begin{tabular}{ccccccc}
\hline \multirow{2}{*}{$\begin{array}{c}\text { Harvest } \\
\text { Time }\end{array}$} & \multicolumn{2}{c}{$\begin{array}{c}\text { Bruised Fruits } \\
(\boldsymbol{\%})\end{array}$} & \multicolumn{2}{c}{$\begin{array}{c}\text { Number of Bruised } \\
\text { Areas / Fruit }\end{array}$} & \multicolumn{2}{c}{$\begin{array}{c}\text { Diameter of Bruised } \\
\text { Area (cm) }\end{array}$} \\
\cline { 2 - 7 } & $\mathbf{2 0 0 6}$ & $\mathbf{2 0 0 7}$ & $\mathbf{2 0 0 6}$ & $\mathbf{2 0 0 7}$ & $\mathbf{2 0 0 6}$ & $\mathbf{2 0 0 7}$ \\
\hline 1 & $6.23 \mathrm{c}$ & $7.04 \mathrm{c}$ & $2.17 \mathrm{~b}$ & $2.67 \mathrm{a}$ & $0.17 \mathrm{c}$ & $0.20 \mathrm{c}$ \\
2 & $10.94 \mathrm{c}$ & $8.85 \mathrm{c}$ & $3.67 \mathrm{ab}$ & $4.33 \mathrm{a}$ & $0.23 \mathrm{c}$ & $0.27 \mathrm{c}$ \\
3 & $16.96 \mathrm{bc}$ & $13.80 \mathrm{bc}$ & $5.67 \mathrm{a}$ & $5.00 \mathrm{a}$ & $0.37 \mathrm{c}$ & $0.40 \mathrm{c}$ \\
4 & $24.66 \mathrm{~b}$ & $26.34 \mathrm{ab}$ & $3.00 \mathrm{~b}$ & $4.00 \mathrm{a}$ & $1.03 \mathrm{~b}$ & $1.33 \mathrm{~b}$ \\
5 & $41.98 \mathrm{a}$ & $34.81 \mathrm{a}$ & $2.83 \mathrm{~b}$ & $2.67 \mathrm{a}$ & $1.83 \mathrm{a}$ & $2.17 \mathrm{a}$ \\
LSD & 11.03 & 16.69 & 2.05 & 3.55 & 0.25 & 0.35 \\
\hline
\end{tabular}

Means within same column having a common letter are not significantly different.
Juice of another two segments was taken and the titratable acidity was determined in three samples as $\mathrm{g}$ 1981).

Three samples of one $\mathrm{g}$ fruit flesh were taken from each treatment to determine its total phenol contents Peluso (1941).

Three samples of $50 \mathrm{~g}$ fruit flesh were taken to estimate the water soluble pectin (WSP) as Ca content according to Care and Hayness (1922).

The termination of the experiment was done by the occurrence of peel shrinkage and flesh mealiness. All data obtained were statistically analyzed according to Snedecor and Cochran (1980). The individual comparisons were carried out by using the Least Significant Difference (LSD) according to SAS Institute (1985). Simple regression coefficient between storage period and studied properties was calculated using SAS Institute (1985).

\section{Fruit Bruising at Harvest:}

There was a significant increase in the bruised fruit percentage during the harvesting two seasons (table 2). This percentage was $6.23 \%$ in 2006 season and $7.04 \%$ in 2007 season at the first harvest and reached the percentages of $41.98 \%$ and $34.81 \%$, respectively at the last harvest. malic acid /100 ml of fruit juice (Chen and Mellenthin, according to the colorimetric method of Resenblatt and 
The above increase in the bruised fruits percentage correlated with the increase in the number of bruised area per each fruit. This number increased (significantly at 2006 season) at the third harvest then declined may be by the attached of the bruised areas where the diameter of those bruised area increased significantly with the progress of the harvesting season from 0.17 and $0.20 \mathrm{~cm}$ at the first harvest to 1.83 and $2.17 \mathrm{~cm}$ at the last one in both seasons, respectively.

From the above results it was noticed that the bruise susceptibility of Swilling peach fruits increased with the advancing of the harvesting season. Many researchers reported similar results on apples (Johnson and Donver, 1990 and Opara, 2007)

The bruised area at the first harvest was characterized by slightly darker color than the other fruit surface and the flesh under those area had different appearance (watery) compared with the sound flesh cells. With the progress of the harvesting season the bruised areas became darker and had water-soaked appearance with a little grove of brownish flesh under the disconnecting peel in those areas (fig 1 and 2).

The discoloration is due to a combination of physical stress and biochemical reactions (Wang and Mellenthin, 1973) where the total phenols correlate with bruising appearance (Kader and Chordas, 1984). The darkening phenomena of the stressed bruised area is caused by the oxidation of the phenolic compounds by polyphenoloxidase enzyme (Berardinelli et al., 2005). Metallic ions in the presence of anthocyanin and phenolic compounds cause formation of dark pigments under normal plant tissue conditions and low $\mathrm{pH}$ depends on the ratio of each (Jurd and Asen, 1966 and Hsia et al., 1965). This ratio can be changed by the cause of any stress on the fruit.

\section{Bruising Susceptibility of Sound Fruits:}

Fruits of the first two harvests had no impact appearance when they dropped from the different heights except a slightly bruised area (1 $\mathrm{mm}$ average) with the $50 \mathrm{~cm}$ height. The flesh of the fruits changed to the brown color after 24 hours at RT. The fruits of the third harvest were not affected by the dropping heights of 20 and $30 \mathrm{~cm}$. On the other hand, the dropping heights of 40 and $50 \mathrm{~cm}$ caused bruised damage of $1 \mathrm{~mm}$ average witch changed to darker brown color after 24 hours at RT compared with the first two harvests. The fruits of the last two harvests were slightly affected by the height of $30 \mathrm{~cm}$ where there was no clear symptom appeared on the peel but the flesh had watery area of $1 \mathrm{~mm}$ diameter. The height of $40 \mathrm{~cm}$ had the same effect but the flesh bruised area was darker. The height of $50 \mathrm{~cm}$ caused clear bruised area (fig 3) and the watery symptoms appeared on the peel and flesh with faster changes to brown color at RT (fig 4).

The previous work on plums and peaches demonstrated that the fruits with higher flesh firmness (early harvests) were highly resistant to impact injury. Firmness is an indicator of how late to safely harvest. However, the decision when to harvest should also take into account other factors, such as fruit drop, environmental conditions, hand labor availability, market prices, distance to market, potential transportation damage and temperature management at the receiving location (Crisosto, 1999 and Crisosto et al., 2004).

\section{Weight Loss (\%):}

In both seasons, the first and second harvests of peach fruits had the significantly highest weight loss during the storage period (table 3) compared with the other three harvests and there were no significant differences between the last ones. With the progress of the storage period fruit weight loss increased significantly $\left(\mathrm{r}^{2}\right.$ values were highly significant in both seasons) in all harvest times.

Although the general observation is that fruits of earlier harvests has less weight loss, because of the fruit shriveling in prunes at the later harvest date that would increase weight loss (Guerra and Casquero, 2008 on Green Gage plum) the results of our study showed greater weight loss in the earlier harvests. That results agree with those of Kluge et al., 1996 and AgulheiroSantos et al., 2006 on Green Gage plums.

The weight loss is mainly a result of water loss from the fruit tissues and partially of the respiration process and that increased with the advancing of storage period (El-Saedy, 1994 and Hussein, 1996).

\section{Flesh Firmness $\left(\mathbf{l b} / \mathbf{i n}^{2}\right)$ :}

Harvest time had a significant effect on flesh firmness. During the harvest seasons, peach flesh firmness decreased significantly from 11.20 to 9.28 $\mathrm{lb} / \mathrm{in}^{2}$ in the first season and from 11.34 to $8.90 \mathrm{lb} / \mathrm{in}^{2}$ in the second season (table 4) with 17.14 and $21.52 \%$ loss percentage, respectively. Those results agree with the results of Crisosto et al., 2004 and; Guerra and Casquero, 2008 on plums and Remorini et al., 2008 on peaches.

The differences between harvest times were less during the storage period in both seasons and the first harvest time had the significant highest firmness at the end of the storage period. Fruits of all the harvest times loss its flesh firmness with the advancing of the storage 


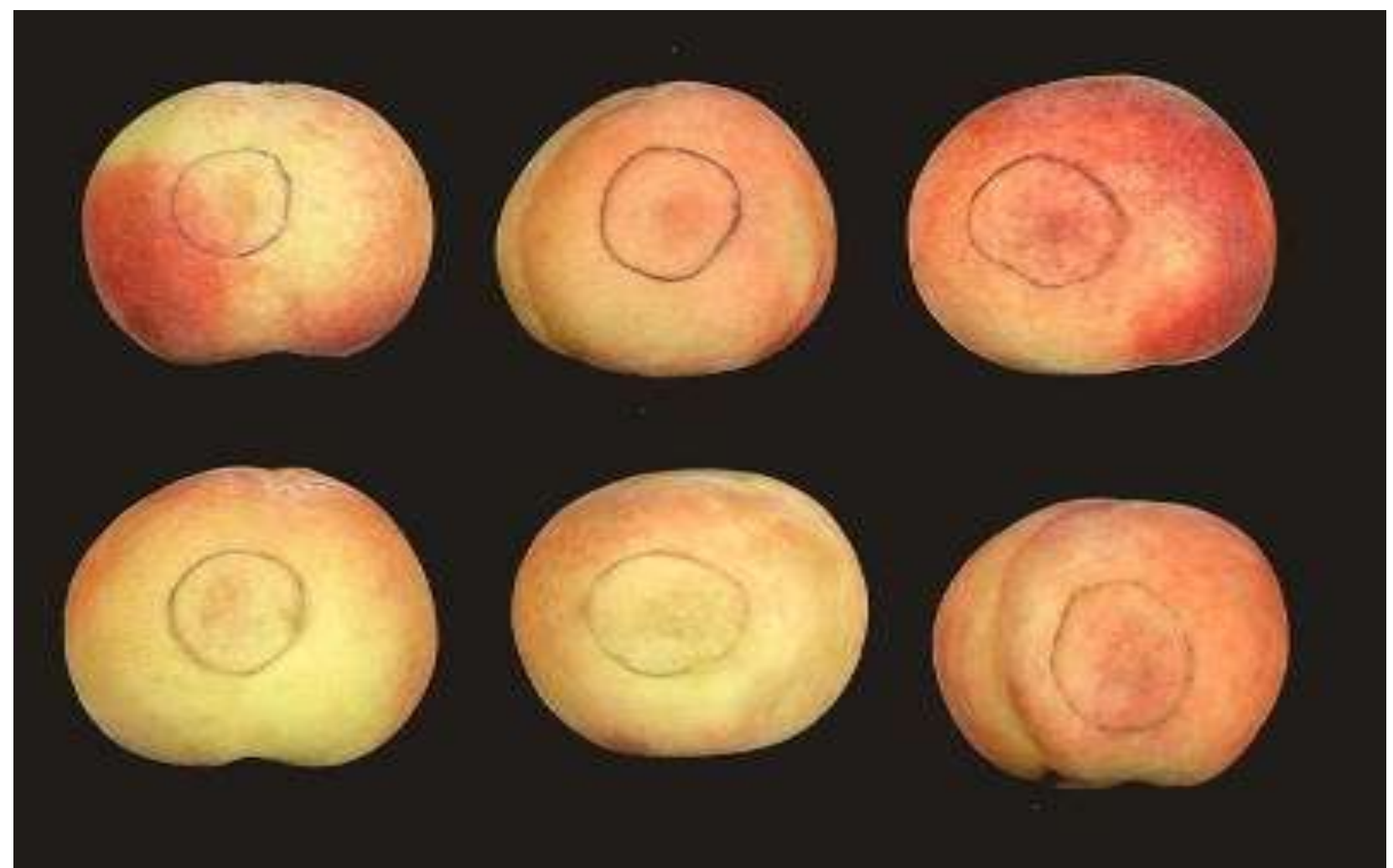

Fig1. Peel Bruising Symptoms of Swilling Peach Fruits at Harvest
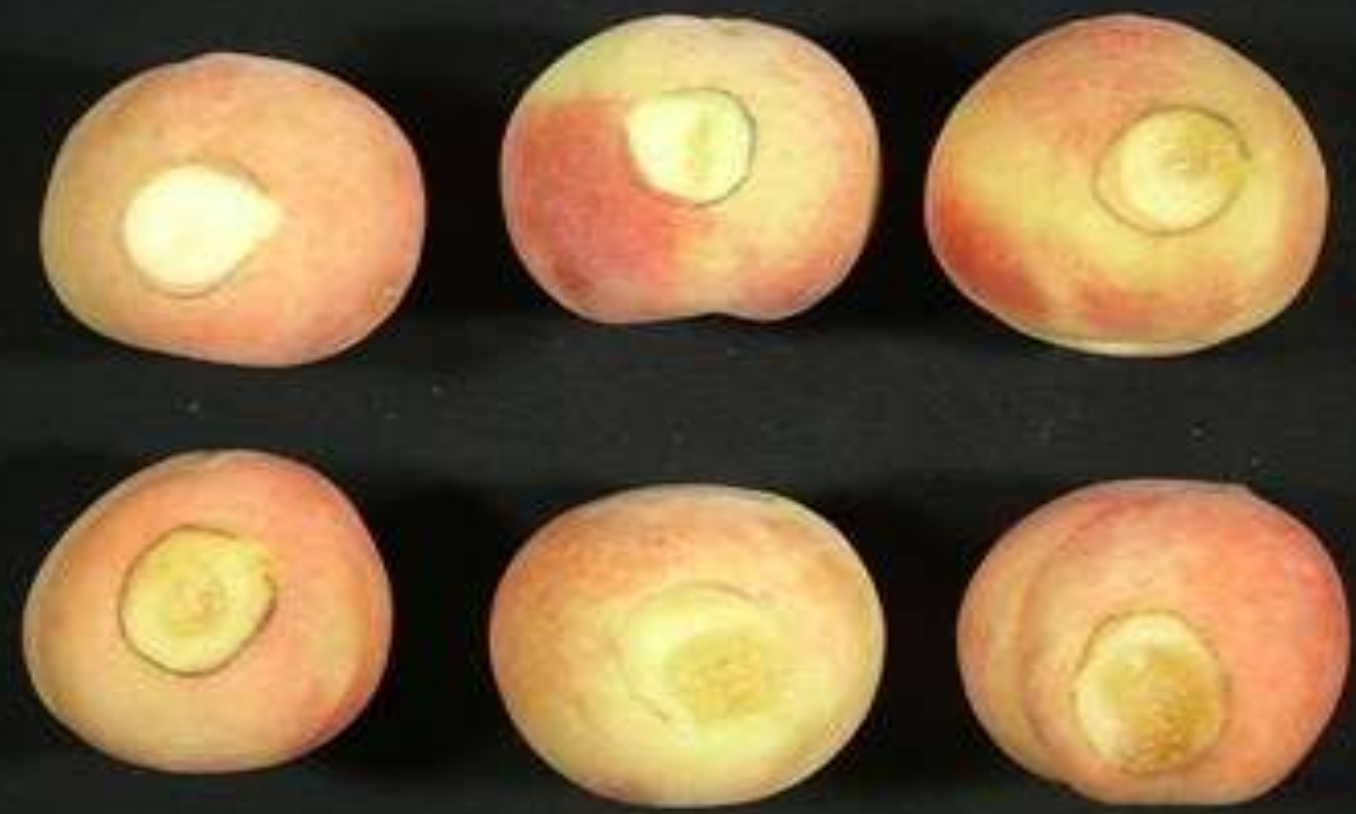

Fig 2. Flesh Bruising Symptoms of Swilling Peach Fruits at Harvest 

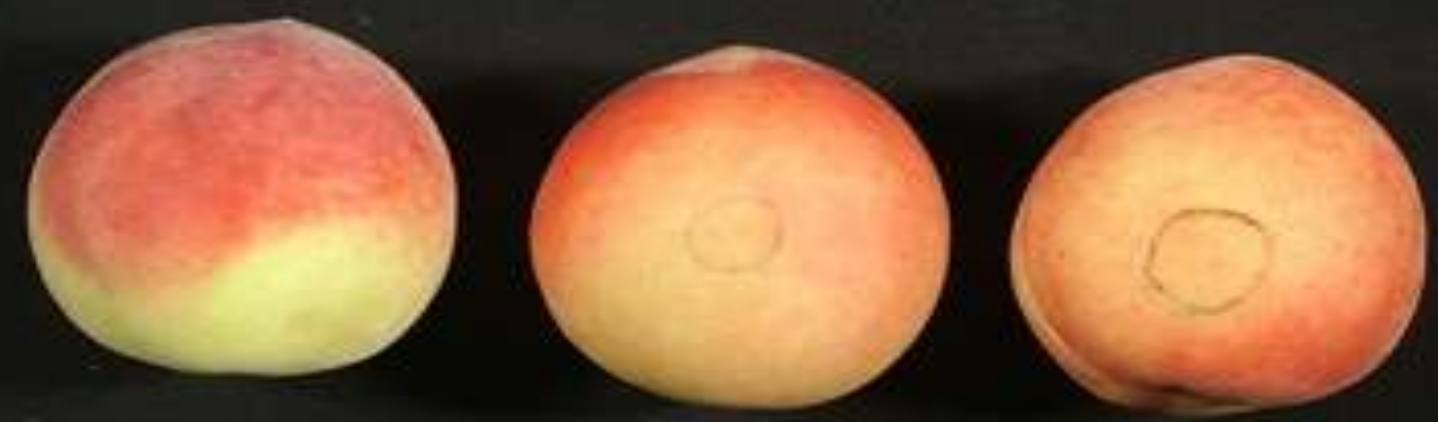

Fig 3. Peel Bruising Appearance of the Fifth Harvest Fruits Dropped from 50cm Height
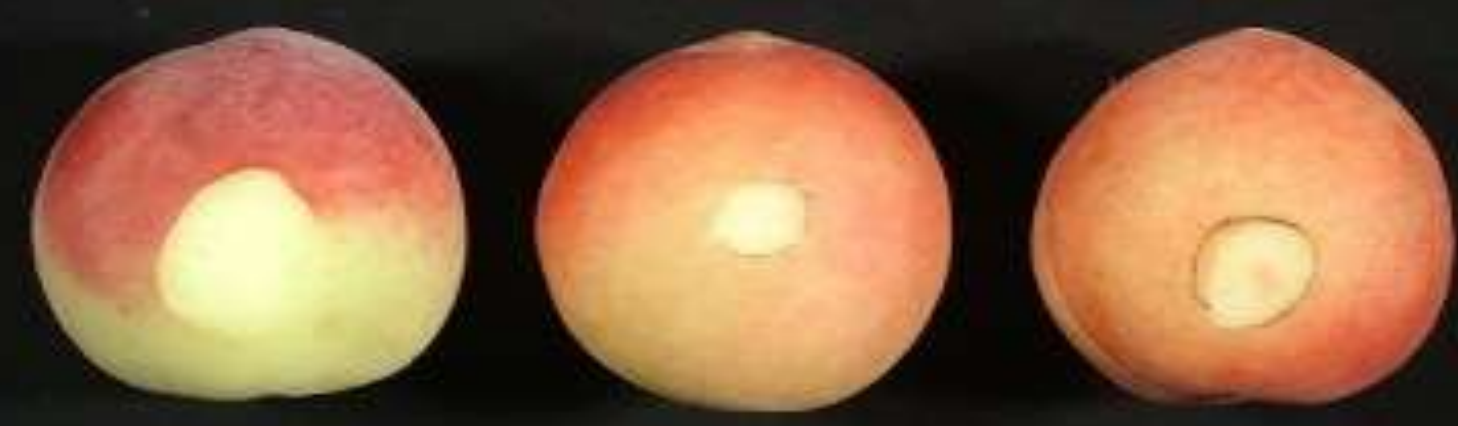

Fig 4. Flesh Bruising Appearance of the Fifth Harvest Fruits Dropped from $50 \mathrm{~cm}$ Height 
Table 3. Effect of Harvest Time and Cold Storage on Weight Loss(\%)of Swilling Peaches on 2006 and 2007 Seasons

\begin{tabular}{cccccccccc}
\hline Harvest & \multicolumn{8}{c}{ Storage Period } \\
\cline { 2 - 10 } Time & $\mathbf{0}$ & $\mathbf{4}$ & $\mathbf{8}$ & $\mathbf{1 2}$ & $\mathbf{1 6}$ & $\mathbf{2 0}$ & $\mathbf{2 4}$ & $\mathbf{2 8}$ & $\mathbf{r}^{\mathbf{2}}$ \\
\hline 2006Season & & & & & & & & & \\
1 & $0.00 \mathrm{a}$ & $4.00 \mathrm{a}$ & $7.61 \mathrm{ab}$ & $10.75 \mathrm{ab}$ & $15.13 \mathrm{ab}$ & $17.51 \mathrm{ab}$ & $24.52 \mathrm{a}$ & $28.99 \mathrm{a}$ & $0.988^{* *}$ \\
2 & $0.00 \mathrm{a}$ & $4.06 \mathrm{a}$ & $8.10 \mathrm{a}$ & $11.86 \mathrm{a}$ & $16.19 \mathrm{a}$ & $20.42 \mathrm{a}$ & $24.40 \mathrm{a}$ & $27.58 \mathrm{ab}$ & $0.999^{* *}$ \\
3 & $0.00 \mathrm{a}$ & $3.28 \mathrm{~b}$ & $6.77 \mathrm{bc}$ & $9.83 \mathrm{~b}$ & $13.20 \mathrm{~b}$ & $18.52 \mathrm{ab}$ & $22.63 \mathrm{ab}$ & $27.00 \mathrm{abc}$ & $0.993 * *$ \\
4 & $0.00 \mathrm{a}$ & $3.22 \mathrm{~b}$ & $5.79 \mathrm{c}$ & $9.25 \mathrm{~b}$ & $12.57 \mathrm{~b}$ & $16.69 \mathrm{~b}$ & $20.33 \mathrm{~b}$ & $22.82 \mathrm{c}$ & $0.997 * *$ \\
5 & $0.00 \mathrm{a}$ & $3.14 \mathrm{~b}$ & $5.98 \mathrm{c}$ & $9.11 \mathrm{~b}$ & $12.71 \mathrm{~b}$ & $17.02 \mathrm{~b}$ & $21.12 \mathrm{ab}$ & $23.63 \mathrm{bc}$ & $0.996^{* *}$ \\
LSD & & 0.57 & 1.26 & 1.81 & 2.57 & 3.28 & 4.02 & 4.18 & \\
\hline 2007 Season & & & & & & & & & \\
1 & $0.00 \mathrm{a}$ & $4.45 \mathrm{a}$ & $8.46 \mathrm{a}$ & $11.81 \mathrm{a}$ & $16.33 \mathrm{ab}$ & $19.21 \mathrm{ab}$ & $26.29 \mathrm{a}$ & $31.27 \mathrm{a}$ & $0.990^{* *}$ \\
2 & $0.00 \mathrm{a}$ & $4.38 \mathrm{a}$ & $8.50 \mathrm{a}$ & $13.45 \mathrm{a}$ & $17.44 \mathrm{a}$ & $20.16 \mathrm{a}$ & $23.74 \mathrm{ab}$ & $27.17 \mathrm{bc}$ & $0.994^{* *}$ \\
3 & $0.00 \mathrm{a}$ & $3.58 \mathrm{~b}$ & $7.55 \mathrm{ab}$ & $11.24 \mathrm{ab}$ & $14.46 \mathrm{bc}$ & $20.24 \mathrm{a}$ & $24.15 \mathrm{ab}$ & $29.22 \mathrm{ab}$ & $0.995^{* *}$ \\
4 & $0.00 \mathrm{a}$ & $3.10 \mathrm{~b}$ & $5.74 \mathrm{c}$ & $9.23 \mathrm{~b}$ & $12.35 \mathrm{c}$ & $16.11 \mathrm{c}$ & $19.47 \mathrm{c}$ & $21.74 \mathrm{~d}$ & $0.997^{* *}$ \\
5 & $0.00 \mathrm{a}$ & $3.40 \mathrm{~b}$ & $6.20 \mathrm{bc}$ & $9.39 \mathrm{~b}$ & $12.53 \mathrm{c}$ & $16.95 \mathrm{bc}$ & $20.80 \mathrm{bc}$ & $23.71 \mathrm{~cd}$ & $0.997 * *$ \\
LSD & & 0.72 & 1.39 & 2.23 & 2.40 & 2.83 & 3.48 & 3.59 & \\
\hline
\end{tabular}

Means within same column having a common letter are not significantly different.

$\mathrm{r}^{2}=$ Determination coefficient.

period $\left(r^{2}\right.$ values were significant in both seasons) due to pectin chains dissolving as a result of the increase in pectin esterase activity (Ben-Arie et al., 1984; Kurnaz and Kaska 1993; Peires et al., 2000 and Malakou and Nanos 2005). But, at the last intervals of storage the fruits became less juicy and had gel texture especially fruits of the first two dates. Those symptoms are due to the chilling injury and are known as mealiness witch characterized by loss of juiciness and pectin gel formation (Manganaris et al., 2008).It is accepted that the textural changes occurring are associated with abnormal modification in the activities of cell walldegrading enzymes, generally leading to alterations in pectin metabolism (Brummell et al., 2004 and Lurie and Crisosto, 2005).

$\operatorname{SSC}(\%)$ :

At harvest time the fruits of the earlier harvests had the significant lowest SSC values (table 5). Those contents increased with the advancing of the harvest season from 10.64 and $12.56 \%$ to 15.28 and $14.56 \%$ in both seasons, respectively.The same results are reported by Crisosto et al.,2004 and; Guerra and Casquero, 2008 on plums and Remorini 2008 et al.,on peaches.

During the storage period, SSC percentages increased $\left(\mathrm{r}^{2}\right.$ values were not significant in most of

Table 4. Effect of Harvest Time and Cold Storage on Flesh Firmness (lb/in $\left.{ }^{2}\right)$ of Swilling Peaches on 2006 and 2007 Seasons

\begin{tabular}{cccccccccc}
\hline Harvest & \multicolumn{8}{c}{ Storage Period } \\
\cline { 2 - 10 } Time & $\mathbf{0}$ & $\mathbf{4}$ & $\mathbf{8}$ & $\mathbf{1 2}$ & $\mathbf{1 6}$ & $\mathbf{2 0}$ & $\mathbf{2 4}$ & $\mathbf{2 8}$ & $\mathbf{r}^{\mathbf{2}}$ \\
\hline 2006Season & & & & & & & & & \\
1 & $11.20 \mathrm{ab}$ & $12.18 \mathrm{a}$ & $10.70 \mathrm{a}$ & $10.49 \mathrm{a}$ & $9.56 \mathrm{a}$ & $10.46 \mathrm{a}$ & $7.95 \mathrm{~b}$ & $7.70 \mathrm{ab}$ & $0.792^{* *}$ \\
2 & $11.76 \mathrm{a}$ & $11.34 \mathrm{a}$ & $10.27 \mathrm{a}$ & $9.64 \mathrm{ab}$ & $8.21 \mathrm{ab}$ & $8.60 \mathrm{ab}$ & $8.23 \mathrm{ab}$ & $8.97 \mathrm{a}$ & $0.769^{* *}$ \\
3 & $10.10 \mathrm{bc}$ & $10.80 \mathrm{ab}$ & $11.21 \mathrm{a}$ & $11.61 \mathrm{a}$ & $9.50 \mathrm{a}$ & $6.92 \mathrm{~b}$ & $5.05 \mathrm{c}$ & $5.66 \mathrm{~b}$ & $0.704^{* *}$ \\
4 & $9.82 \mathrm{bc}$ & $10.83 \mathrm{ab}$ & $11.44 \mathrm{a}$ & $9.91 \mathrm{a}$ & $7.64 \mathrm{~b}$ & $9.60 \mathrm{a}$ & $10.04 \mathrm{a}$ & $7.99 \mathrm{a}$ & $0.508^{* *}$ \\
5 & $9.28 \mathrm{c}$ & $9.48 \mathrm{~b}$ & $8.17 \mathrm{~b}$ & $7.69 \mathrm{~b}$ & $9.25 \mathrm{ab}$ & $10.00 \mathrm{a}$ & $8.52 \mathrm{ab}$ & $6.84 \mathrm{ab}$ & $0.569^{*}$ \\
LSD & 1.40 & 1.74 & 1.44 & 2.15 & 1.82 & 2.62 & 2.00 & 2.27 & \\
\hline 2007 Season & & & & & & & & & \\
1 & $11.34 \mathrm{a}$ & $13.47 \mathrm{a}$ & $11.10 \mathrm{a}$ & $11.58 \mathrm{a}$ & $10.14 \mathrm{a}$ & $11.00 \mathrm{a}$ & $7.67 \mathrm{ab}$ & $8.63 \mathrm{a}$ & $0.567^{*}$ \\
2 & $11.48 \mathrm{a}$ & $10.02 \mathrm{bc}$ & $9.99 \mathrm{a}$ & $8.49 \mathrm{~b}$ & $9.62 \mathrm{a}$ & $9.91 \mathrm{a}$ & $8.72 \mathrm{a}$ & $7.61 \mathrm{ab}$ & $0.649^{*}$ \\
3 & $10.48 \mathrm{a}$ & $9.85 \mathrm{bc}$ & $9.02 \mathrm{a}$ & $10.02 \mathrm{ab}$ & $9.51 \mathrm{a}$ & $9.30 \mathrm{ab}$ & $6.15 \mathrm{~b}$ & $6.51 \mathrm{bc}$ & $0.681^{*}$ \\
4 & $9.96 \mathrm{ab}$ & $10.90 \mathrm{~b}$ & $9.61 \mathrm{a}$ & $9.23 \mathrm{~b}$ & $8.36 \mathrm{a}$ & $8.98 \mathrm{ab}$ & $9.05 \mathrm{a}$ & $5.82 \mathrm{~cd}$ & $0.646^{*}$ \\
5 & $8.90 \mathrm{~b}$ & $8.67 \mathrm{c}$ & $9.63 \mathrm{a}$ & $11.03 \mathrm{a}$ & $9.73 \mathrm{a}$ & $7.36 \mathrm{~b}$ & $7.06 \mathrm{ab}$ & $4.40 \mathrm{~d}$ & $0.560^{*}$ \\
LSD & 1.54 & 1.76 & 2.11 & 1.59 & 2.10 & 2.06 & 2.24 & 1.77 & \\
\hline
\end{tabular}

Means within same column having a common letter are not significantly different.

$\mathrm{r}^{2}=$ Determination coefficient. 
Table 5. Effect of Harvest Time and Cold Storage on SSC (\%) of Swilling Peaches on 2006 and 2007 Seasons

\begin{tabular}{cccccccccc}
\hline Harvest & \multicolumn{8}{c}{ Storage Period } \\
\cline { 2 - 10 } Time & $\mathbf{0}$ & $\mathbf{4}$ & $\mathbf{8}$ & $\mathbf{1 2}$ & $\mathbf{1 6}$ & $\mathbf{2 0}$ & $\mathbf{2 4}$ & $\mathbf{2 8}$ & $\mathbf{r}^{\mathbf{2}}$ \\
\hline 2006Season & & & & & & & & & \\
1 & $10.64 \mathrm{c}$ & $11.93 \mathrm{~b}$ & $13.20 \mathrm{ab}$ & $14.27 \mathrm{a}$ & $12.60 \mathrm{~b}$ & $12.80 \mathrm{bc}$ & $14.93 \mathrm{a}$ & $14.20 \mathrm{a}$ & $0.600^{*}$ \\
2 & $12.20 \mathrm{bc}$ & $11.80 \mathrm{~b}$ & $14.13 \mathrm{a}$ & $12.07 \mathrm{~b} \mathrm{c}$ & $12.53 \mathrm{~b}$ & $12.53 \mathrm{c}$ & $11.93 \mathrm{c}$ & $14.60 \mathrm{a}$ & 0.131 \\
3 & $12.76 \mathrm{~b}$ & $11.20 \mathrm{~b}$ & $12.47 \mathrm{bc}$ & $12.80 \mathrm{~b}$ & $12.73 \mathrm{ab}$ & $13.93 \mathrm{a}$ & $13.87 \mathrm{~b}$ & $13.20 \mathrm{~b}$ & 0.491 \\
4 & $13.64 \mathrm{ab}$ & $13.13 \mathrm{a}$ & $11.27 \mathrm{c}$ & $11.47 \mathrm{c}$ & $13.07 \mathrm{ab}$ & $14.13 \mathrm{a}$ & $15.07 \mathrm{a}$ & $14.53 \mathrm{a}$ & 0.312 \\
5 & $15.28 \mathrm{a}$ & $11.67 \mathrm{~b}$ & $12.40 \mathrm{bc}$ & $11.67 \mathrm{bc}$ & $13.53 \mathrm{a}$ & $13.20 \mathrm{~b}$ & $15.67 \mathrm{a}$ & $14.67 \mathrm{a}$ & 0.138 \\
LSD & 1.89 & 1.02 & 1.54 & 1.22 & 0.90 & 0.54 & 0.92 & 0.79 & \\
\hline 2007 Season & & & & & & & & & \\
1 & $12.56 \mathrm{~b}$ & $11.73 \mathrm{~b}$ & $11.87 \mathrm{bc}$ & $11.80 \mathrm{~b}$ & $12.67 \mathrm{c}$ & $12.93 \mathrm{c}$ & $12.27 \mathrm{c}$ & $13.87 \mathrm{bc}$ & 0.417 \\
2 & $12.80 \mathrm{ab}$ & $12.07 \mathrm{~b}$ & $13.07 \mathrm{a}$ & $12.00 \mathrm{~b}$ & $11.13 \mathrm{~d}$ & $13.47 \mathrm{~b}$ & $14.07 \mathrm{~b}$ & $13.27 \mathrm{c}$ & 0.176 \\
3 & $12.32 \mathrm{~b}$ & $12.00 \mathrm{~b}$ & $13.40 \mathrm{a}$ & $13.47 \mathrm{a}$ & $12.80 \mathrm{bc}$ & $14.07 \mathrm{a}$ & $15.07 \mathrm{a}$ & $14.40 \mathrm{ab}$ & $0.753^{*}$ \\
4 & $14.48 \mathrm{a}$ & $13.07 \mathrm{a}$ & $11.13 \mathrm{c}$ & $13.47 \mathrm{a}$ & $14.07 \mathrm{a}$ & $14.13 \mathrm{a}$ & $15.13 \mathrm{a}$ & $14.87 \mathrm{a}$ & 0.269 \\
5 & $14.56 \mathrm{a}$ & $11.53 \mathrm{~b}$ & $12.20 \mathrm{~b}$ & $13.27 \mathrm{a}$ & $13.27 \mathrm{~b}$ & $13.27 \mathrm{~b}$ & $14.73 \mathrm{ab}$ & $14.88 \mathrm{a}$ & 0.266 \\
LSD & 1.77 & 0.66 & 0.83 & 0.98 & 0.55 & 0.31 & 0.94 & 0.98 & \\
\hline
\end{tabular}

Means within same column having a common letter are not significantly different.

$r^{2}=$ Determination coefficient.

harvest times) with the progress of storage time and the late harvests had the highest fruit SSC. That increase could be due to the degradation of complex insoluble pectins to simple soluble sugars the major component of SSC in fruits. The above results and discussion agree with Hussein, 1996 and; Mohamed, 1999 on peaches and Guerra and Casquero, 2008 on plums.

Titratable Acidity (TA \%):

The tabulated data (table 6) showed that fruits of the last harvest time had the significant lowest TA compared with the earlier ones. At the first harvest time the TA values were 0.37 and $0.32 \%$ in 2006 and 2007 seasons, respectively and reached 0.24 and $0.25 \%$ at the last harvest time. This finding agree with those of Crisosto et al., 2004 on plums and Remorini et al., 2008 on peaches but no changes were reported by Guerra and Casquero, 2008 on plums.

During storage no constant differences were found between harvesting times and all the values of TA that decreased with the advancing of storage period $\left(\operatorname{most} \mathrm{r}^{2}\right.$ values were highly significant) as a result of the consumption of malic acid in respiration according to the reports of Hussein, 1996; Mohamed, 1999 on peaches; Guerra and Casquero, 2008 on plums and Malakou and Nanos, 2005 on peaches and nectarines.

Table 6. Effect of Harvest Time and Cold Storage on TA (\%) of Swilling Peaches on 2006 and 2007 Seasons

\begin{tabular}{|c|c|c|c|c|c|c|c|c|c|}
\hline \multirow{2}{*}{$\begin{array}{c}\text { Harvest } \\
\text { Time }\end{array}$} & \multicolumn{9}{|c|}{ Storage Period } \\
\hline & $\mathbf{0}$ & 4 & 8 & 12 & 16 & 20 & 24 & 28 & $\mathbf{r}^{2}$ \\
\hline \multicolumn{10}{|l|}{ 2006Season } \\
\hline 1 & $0.37 \mathrm{a}$ & $0.28 \mathrm{a}$ & $0.21 b$ & $0.23 \mathrm{a}$ & $0.20 \mathrm{~b}$ & $0.27 \mathrm{a}$ & $0.19 \mathrm{ab}$ & $0.20 \mathrm{a}$ & $0.509^{*}$ \\
\hline 2 & $0.32 \mathrm{ab}$ & $0.29 a$ & $0.22 b$ & $0.23 \mathrm{a}$ & $0.25 \mathrm{a}$ & $0.23 b$ & $0.21 \mathrm{a}$ & $0.15 b$ & $0.761 * *$ \\
\hline 3 & $0.27 b c$ & $0.26 \mathrm{a}$ & $0.28 \mathrm{a}$ & $0.25 \mathrm{a}$ & $0.21 \mathrm{~b}$ & $0.19 \mathrm{c}$ & $0.21 \mathrm{a}$ & $0.21 \mathrm{a}$ & $0.715 * *$ \\
\hline 4 & $0.30 \mathrm{c}$ & $0.24 \mathrm{a}$ & $0.28 \mathrm{a}$ & $0.26 \mathrm{a}$ & $0.27 \mathrm{a}$ & $0.24 b$ & $0.17 b$ & $0.23 \mathrm{a}$ & 0.493 \\
\hline 5 & $0.24 c$ & $0.24 \mathrm{a}$ & $0.25 \mathrm{ab}$ & $0.22 \mathrm{a}$ & $0.25 \mathrm{a}$ & $0.20 \mathrm{c}$ & $0.20 \mathrm{ab}$ & $0.22 \mathrm{a}$ & 0.430 \\
\hline LSD & 0.06 & 0.06 & 0.04 & 0.04 & 0.04 & 0.02 & 0.04 & 0.03 & \\
\hline \multicolumn{10}{|l|}{ 2007Season } \\
\hline 1 & $0.32 \mathrm{a}$ & $0.28 \mathrm{ab}$ & $0.33 \mathrm{a}$ & $0.25 \mathrm{a}$ & $0.23 \mathrm{a}$ & $0.24 \mathrm{a}$ & $0.18 \mathrm{~b}$ & $0.20 \mathrm{~b}$ & $0.791 * *$ \\
\hline 2 & $0.31 \mathrm{ab}$ & $0.28 \mathrm{ab}$ & $0.26 \mathrm{c}$ & $0.24 a b$ & $0.25 \mathrm{a}$ & $0.21 \mathrm{bc}$ & $0.24 \mathrm{a}$ & $0.17 \mathrm{c}$ & $0.823 * *$ \\
\hline 3 & $0.30 \mathrm{ab}$ & $0.29 \mathrm{ab}$ & $0.25 \mathrm{c}$ & $0.22 b$ & $0.26 \mathrm{a}$ & $0.18 \mathrm{c}$ & $0.19 b$ & $0.21 \mathrm{~b}$ & $0.721 * *$ \\
\hline 4 & $0.31 \mathrm{ab}$ & $0.25 b$ & $0.28 b c$ & $0.25 \mathrm{ab}$ & $0.26 a$ & $0.24 \mathrm{ab}$ & $0.19 b$ & $0.24 \mathrm{a}$ & $0.577 *$ \\
\hline 5 & $0.25 b$ & $0.32 \mathrm{a}$ & $0.30 \mathrm{ab}$ & $0.24 \mathrm{ab}$ & $0.27 \mathrm{a}$ & $0.21 \mathrm{abc}$ & $0.20 \mathrm{~b}$ & $0.25 \mathrm{a}$ & 0.371 \\
\hline LSD & 0.07 & 0.05 & 0.04 & 0.03 & 0.05 & 0.03 & 0.03 & 0.02 & \\
\hline
\end{tabular}

Means within same column having a common letter are not significantly different.

$r^{2}=$ Determination coefficient. 
Water Soluble Pectin (WSP \%):

The results of flesh WSP percentage (table 7) at harvest showed that the later harvest time the highest WSP content in peach fruits where the last harvest time had the highest significant value of WSP and that reflected the lowest flesh firmness. Similar results were reported by Levaj et al., 2003 on peach.

The percentage WSP increased also with the progress of cold storage where most $\mathrm{r}^{2}$ values were significant (El-Saedy, 2000 and Levaj et al., 2003).

Total Phenols (\%):
Fruits of the first and second harvest times had the highest initial percentages of total phenols (table 8). Those percentages decreased during the first days of cold storage then increased in some harvest times in both seasons. Malakou and Nanos, 2005 recorded an increase of total phenol contents of peach fruits after one week of cold storage.

With the progress of cold storage, all total phenol values decreased but the effect was not significant. Malakou and Nanos, 2005 reported that durations in cold storage did not have any major effect on total phenols of peaches.

Table 7. Effect of Harvest Time and Cold Storage on WSP (\%) of Swilling Peaches on 2006 and 2007 Seasons

\begin{tabular}{cccccccccc}
\hline Harvest & \multicolumn{8}{c}{ Storage Period } \\
\cline { 2 - 10 } Time & $\mathbf{0}$ & $\mathbf{4}$ & $\mathbf{8}$ & $\mathbf{1 2}$ & $\mathbf{1 6}$ & $\mathbf{2 0}$ & $\mathbf{2 4}$ & $\mathbf{2 8}$ & $\mathbf{r}^{2}$ \\
\hline 2006Season & & & & & & & & & \\
1 & $0.32 \mathrm{bc}$ & $0.50 \mathrm{bc}$ & $0.51 \mathrm{~b}$ & $0.46 \mathrm{~b}$ & $0.29 \mathrm{~b}$ & $0.68 \mathrm{~b}$ & $0.98 \mathrm{~b}$ & $0.82 \mathrm{~b}$ & $0.573^{*}$ \\
2 & $0.28 \mathrm{c}$ & $0.25 \mathrm{c}$ & $0.62 \mathrm{~b}$ & $0.90 \mathrm{ab}$ & $0.54 \mathrm{ab}$ & $1.07 \mathrm{ab}$ & $0.93 \mathrm{~b}$ & $0.85 \mathrm{~b}$ & $0.633^{*}$ \\
3 & $0.47 \mathrm{bc}$ & $1.01 \mathrm{a}$ & $0.82 \mathrm{ab}$ & $1.01 \mathrm{ab}$ & $1.22 \mathrm{a}$ & $1.28 \mathrm{ab}$ & $1.73 \mathrm{a}$ & $1.14 \mathrm{ab}$ & $0.621^{*}$ \\
4 & $0.65 \mathrm{ab}$ & $0.85 \mathrm{a}$ & $1.10 \mathrm{a}$ & $1.00 \mathrm{ab}$ & $0.80 \mathrm{ab}$ & $1.67 \mathrm{a}$ & $1.45 \mathrm{ab}$ & $1.60 \mathrm{ab}$ & $0.706^{* *}$ \\
5 & $1.00 \mathrm{a}$ & $0.56 \mathrm{~b}$ & $0.85 \mathrm{ab}$ & $1.54 \mathrm{a}$ & $1.03 \mathrm{ab}$ & $1.85 \mathrm{a}$ & $1.91 \mathrm{a}$ & $1.79 \mathrm{a}$ & $0.690^{*}$ \\
LSD & 0.37 & 0.26 & 0.37 & 0.85 & 0.75 & 0.89 & 0.69 & 0.89 & \\
\hline 2007 Season & & & & & & & & & \\
1 & $0.33 \mathrm{~b}$ & $0.46 \mathrm{a}$ & $1.00 \mathrm{a}$ & $0.70 \mathrm{a}$ & $0.92 \mathrm{c}$ & $1.26 \mathrm{a}$ & $0.88 \mathrm{~b}$ & $0.46 \mathrm{c}$ & 0.134 \\
2 & $0.36 \mathrm{ab}$ & $0.44 \mathrm{a}$ & $0.64 \mathrm{a}$ & $0.70 \mathrm{a}$ & $0.93 \mathrm{bc}$ & $1.52 \mathrm{a}$ & $0.98 \mathrm{~b}$ & $1.53 \mathrm{abc}$ & $0.806^{* *}$ \\
3 & $0.38 \mathrm{ab}$ & $0.78 \mathrm{a}$ & $1.33 \mathrm{a}$ & $1.06 \mathrm{a}$ & $1.37 \mathrm{ab}$ & $1.46 \mathrm{a}$ & $1.85 \mathrm{a}$ & $0.92 \mathrm{bc}$ & 0.395 \\
4 & $0.54 \mathrm{ab}$ & $0.82 \mathrm{a}$ & $1.09 \mathrm{a}$ & $1.14 \mathrm{a}$ & $1.23 \mathrm{abc}$ & $1.75 \mathrm{a}$ & $1.60 \mathrm{ab}$ & $1.72 \mathrm{ab}$ & $0.914^{* *}$ \\
5 & $0.60 \mathrm{a}$ & $1.15 \mathrm{a}$ & $1.26 \mathrm{a}$ & $0.80 \mathrm{a}$ & $1.44 \mathrm{a}$ & $1.63 \mathrm{a}$ & $1.73 \mathrm{a}$ & $2.27 \mathrm{a}$ & $0.799^{* *}$ \\
LSD & 0.26 & 0.75 & 0.80 & 0.70 & 0.45 & 0.69 & 0.75 & 1.19 & \\
\hline
\end{tabular}

Means within same column having a common letter are not significantly different.

$\mathrm{r}^{2}=$ Determination coefficient.

Table 8. Effect of Harvest Time and Cold Storage on Total Phenols (\%) of Swilling Peaches on 2006 and 2007 Seasons

\begin{tabular}{|c|c|c|c|c|c|c|c|c|c|}
\hline \multirow{2}{*}{$\begin{array}{c}\text { Harvest } \\
\text { Time }\end{array}$} & \multicolumn{9}{|c|}{ Storage Period } \\
\hline & $\mathbf{0}$ & 4 & 8 & 12 & 16 & 20 & 24 & 28 & $\mathbf{r}^{2}$ \\
\hline \multicolumn{10}{|l|}{ 2006Season } \\
\hline 1 & $0.43 \mathrm{a}$ & $0.32 \mathrm{a}$ & $0.31 \mathrm{a}$ & $0.49 \mathrm{a}$ & $0.29 \mathrm{ab}$ & $0.31 \mathrm{a}$ & $0.32 \mathrm{a}$ & $0.25 \mathrm{a}$ & 0.290 \\
\hline 2 & $0.48 \mathrm{a}$ & $0.35 \mathrm{a}$ & $0.30 \mathrm{a}$ & $0.40 \mathrm{a}$ & $0.43 \mathrm{a}$ & $0.26 \mathrm{a}$ & $0.27 \mathrm{a}$ & $0.27 \mathrm{a}$ & 0.467 \\
\hline 3 & $0.34 \mathrm{a}$ & $0.34 \mathrm{a}$ & $0.37 \mathrm{a}$ & $0.44 a$ & $0.38 \mathrm{ab}$ & $0.31 \mathrm{a}$ & $0.34 \mathrm{a}$ & $0.28 \mathrm{a}$ & 0.160 \\
\hline 4 & $0.37 \mathrm{a}$ & $0.31 \mathrm{a}$ & $0.41 \mathrm{a}$ & $0.51 \mathrm{a}$ & $0.23 b$ & $0.24 \mathrm{a}$ & $0.29 \mathrm{a}$ & $0.24 \mathrm{a}$ & 0.282 \\
\hline 5 & $0.36 \mathrm{a}$ & $0.31 \mathrm{a}$ & $0.42 \mathrm{a}$ & $0.34 \mathrm{a}$ & $0.33 \mathrm{ab}$ & $0.32 \mathrm{a}$ & $0.29 \mathrm{a}$ & $0.23 \mathrm{a}$ & 0.494 \\
\hline LSD & 0.24 & 0.18 & 0.148 & 0.17 & 0.18 & 0.13 & 0.14 & 0.12 & \\
\hline \multicolumn{10}{|l|}{ 2007Season } \\
\hline 1 & $0.46 \mathrm{ab}$ & $0.39 a$ & $0.38 \mathrm{a}$ & $0.39 a$ & $0.41 \mathrm{a}$ & $0.33 \mathrm{a}$ & $0.31 \mathrm{a}$ & $0.26 \mathrm{a}$ & $0.798^{*}$ \\
\hline 2 & $0.51 \mathrm{a}$ & $0.43 \mathrm{a}$ & $0.37 \mathrm{a}$ & $0.34 \mathrm{a}$ & $0.28 \mathrm{a}$ & $0.29 \mathrm{a}$ & $0.28 \mathrm{a}$ & $0.26 \mathrm{a}$ & $0.867 *$ \\
\hline 3 & $0.33 b$ & $0.32 \mathrm{a}$ & $0.37 \mathrm{a}$ & $0.45 \mathrm{a}$ & $0.37 \mathrm{a}$ & $0.33 \mathrm{a}$ & $0.31 \mathrm{a}$ & $0.27 \mathrm{a}$ & 0.132 \\
\hline 4 & $0.36 \mathrm{ab}$ & $0.29 a$ & $0.35 \mathrm{a}$ & $0.45 \mathrm{a}$ & $0.25 \mathrm{a}$ & $0.23 \mathrm{a}$ & $0.27 \mathrm{a}$ & $0.20 \mathrm{a}$ & 0.401 \\
\hline 5 & $0.32 b$ & $0.27 \mathrm{a}$ & $0.31 \mathrm{a}$ & $0.39 a$ & $0.25 \mathrm{a}$ & $0.27 \mathrm{a}$ & $0.35 \mathrm{a}$ & $0.19 \mathrm{a}$ & 0.130 \\
\hline LSD & 0.15 & 0.19 & 0.14 & 0.18 & 0.23 & 0.14 & 0.11 & 0.15 & \\
\hline
\end{tabular}

Means within same column having a common letter are not significantly different.

$r^{2}=$ Determination coefficient. 


\section{CONCLUSION}

Stone fruits are one of the important fruits for human health due to its contents of carotenoids and phenolic compounds the major sources of antioxidants. Harvesting time influences quality parameters of peach fruits like flesh firmness, SSC, TA, background color and fruit appearance which is one of the important features used by consumer to choose peaches. It is important to determine the optimal time for harvest with high flesh firmness to ensure maximum resistance for handling and do not delay harvest to get any increase in SSC. Peach fruits must be picked, packed and transported gently to avoid bruising (the major surface defect of peach fruits which lead to qualitative and quantitative losses), maintain fruit quality and to increase storage period and its shelf life. Also, Swilling peach fruits should be marketed and consumed within three weeks to avoid mealiness or firmness loss and as a result its quality.

\section{REFERENCES}

Agulheiro-Santos, A. C.; M. G. Pacheco Ribeiro and M. J. Bernalte (2006). Conservatión de ciruela Rainhia Cláudia Verde.[ C. F. Guerra, M. and P. A. Casquero (2008). Effect of harvest date on cold storage and postharvest quality of plum cv. Green Gage. Postharvest Biology and Technology, 47: 325-332].

Ben-Arie, R.; A. Hass; Z. Shoshani; E. Ben-Lev; M. Zeidman and Y. Zutkhi (1984). The effect of precooling Perlette table grapes wrapped in varios plastic films on their keeping quality during air and sea export. Hassadeh, 64 (7): 1380 - 1387. (C. F. Agr. Eng. Abst., 9: 4145).

Berardinelli, A..; V. Donati; A. Giunchi; A. Guarnieri and L. Rangi (2005). Damage to pears caused by simulated transport. Journal of Food Engineering, 66 (2): 219 226.

Bollen, A. F. (2002). Techniques for predicting damage during postharvest handling of perishable products.[C. F. Opara, L. U. (2007). Bruise susceptibilities of Gala apples as affected by orchard management practices and harvest date. Postharvest Biology and Technology, 43: $47-54]$.

Brummel, D. A.; V.Dal Cin; S. Lurie; C. H. Crisosto and J. M. Labavitch (2004). Cell wall metabolism during the development of chilling injury in cold-stored peach fruit.[ C. F. Manganaris, G. A.; A. R. Vicente; C. H. Crisosto and J. M. Labavitch (2008). Cell wall modification in chilling-injured plum fruit (Prunus salicina). Postharvest Biology and Technology, 48: 77 83].

Care, M. H. and S. Haynes (1922). Estimation of pectic substances. [ C.F. Ranganna, S. (1979). Mannaul of Analysis Fruit and Vegitables Products. New Delhi, Tale
Mc Graw-Hill Publishing, Company. Chapter 2: 29 - 33]

Chen, P. M. and W. M. Mellenthin (1981). Effects of harvest date on ripening capacity and post-harvest life of d Anjou pears. J. Amer. Soc. Hort. Sci. 106 (1): 38- 42.

Crisosto, C. H. (1999). Optimum procedures for ripening stone fruit.[ C. F. Crisosto, C. H.; D. Graner; G. M. Crisosto and E. Bowerman (2004). Increasing Blackamber plum (Prunus salicia Lindell) consumer acceptance. Postharvest Biology and Technology, 34: 237 $-244]$.

Crisosto, C. H.; D. Graner; G. M. Crisosto and E. Bowerman (2004). Increasing Blackamber plum (Prunus salicia Lindell) consumer acceptance. Postharvest Biology and Technology, 34: 237 - 244.

Crisosto, C. H; R. S. Johnson and J. Luza (1993). Incidence of physical damage on peach and nectarine skin discoloration development: Anatomical studies. J. Amer. Soc. Hort. Sci., 118 (6): 796 - 800.

El-Saedy, R. M. (1994). Physiological studies on cooling and refrigerated storage of fresh Le Conte pears. M. Sc. Thesis, Alex. Univ., Egypt.

El-Saedy, R. M. (2000). Postharvest- prestorage- calcium treatments in relation to quality changes and storagability of peaches. Ph. D. Thesis, Alexandria University, Alexandria, Egypt.

Guerra, M. and P. A. Casquero (2008). Effect of harvest date on cold storage and postharvest quality of plum cv. Green Gage. Postharvest Biology and Technology, 47: 325 332 .

Gutierrez, A.; J. A. Burgos and E. Moltó (2007). Precommercial sorting line for peaches firmness assessment. Journal of Food Engineering, 81: 721 - 727.

Hsia, C. L.; B. S. Luh and C. O. Chichester (1965). Anthocyanins in freestone peaches. J. Food Sc., 30: 5 12.

Hussein, A. M. (1996). Development of harvest maturity indices and postharvest handling procedures for newly introduced peach cultivars in north west region of Egypt. ATUT Final Report, Ministry of Agriculture and Land Reclamation, Egypt.

Johnson, D. S. and C. J. Donver (1990). Factors influencing the bruise susceptibility of Bramley`s seedling apples.[C.F. Opara, L.U.(2007). Bruise susceptibilities of Gala apples as affected by orchard management practices and harvest date. Postharvest Biology and Technology, 43:47-54].

Jurd, L. and S. Asen (1966). The formation of metal and copigment complex of cyaniding-3-glucoside. Phytochemistry, 5: 1263 - 1271.

Kader, A. A. (1999). Fruit maturity, ripening and quality relationships. Acta Hort., 485: 203-208.

Kader, A. A. and A. Chordas (1984). Evaluating the browning potential of peaches. California Agriculture. March April, 14 - 15. 
Kluge, R. A.; A. B. Bilhava and R. F. F. Cantillano (1996). Cold storage of Reubennel plums (Prunus salicia Lindell).[ C. F. Guerra, M. and P. A. Casquero (2008). Effect of harvest date on cold storage and postharvest quality of plum cv. Green Gage. Postharvest Biology and Technology, 47: 325 - 332].

Kurnaz, S. and N. Kaska (1993). Investigations on the postharvest physiology of some peach varieties grown in Adana. Doga, Türk Tarim Ve Ormancilik Dergisi, 17 (1): 39 - 51. [C. F. Hort. Abst., 65: 1885].

Labavitch,J. M.; L. C. Greve and E. Mitcham (1998). Fruit bruising: It is more than skin deep. Perishables handling Quarterly, 95: 7 - 9.

Levaj, B.; V. Dragovic-Uzelac; A. Dancevic and J. Frlan (2003). The effect of ripening and storage on peach pectin and gel strength of related jams. Acta Alimentaria, 32 (4): 329 - 340.

Lurie S. and C. H. Crisosto (2005). Chilling injury in peach and nectarine. Postharvest Biology and Technology, 37: 195 - 208.

Malakou, A. and G. D. Nanos (2005). A combination of hot water treatment and modified atmosphere packing maintains quality of advanced maturity Caldesi 2000 nectarines and Royal Glory peaches. Postharvest Biology and Technology, 38: 106 - 114.

Manganaris, G. A.; A. R. Vicente; C. H. Crisosto and J. M. Labavitch (2008). Cell wall modification in chillinginjured plum fruit (Prunus salicina). Postharvest Biology and Technology, 48: 77 - 83.
Mohamed Kh. S. (1999). Postharvest studies on newly introduced peach varieties in the north west region of Egypt. M. Sc. Thesis, Fac. Agric., Alex., Egypt.

Opara, L. U. (2007). Bruise susceptibilities of Gala apples as affected by orchard management practices and harvest date. Postharvest Biology and Technology, 43:47 - 54.

Peirs, A.; V. Parmentier; H. Wustenberghs and J. Keulemans (2000). Comparison of quality evaluation during storage between different cultivars of plums. Acta Hort., 518: 145 -150 .

Remorini, D.; S. Tavarini; E. Degl' Innocenti; F. Loreti; R. Massai and Guidi (2008). Effect of rootstocks and harvesting time on the nutrional quality of peel and flesh of peach fruits. Food Chemistry, 110: 361 - 367.

Resenblatt, M. and J.V. Peluso (1941). Determination of Tannins by spectrophotometer. J.Asso. Offic. Agric. Chemists, 24:170.

SAS (1985). SAS user` guide statistics for personal computers version $5^{\text {th }}$ ed. SAS Inst. Cary NCO.

Snedecor, G. W. and W. G. Cochran (1980). Statistical Methods. $7^{\text {th }}$ Ed., Fourth Printing, the Iowa State Univ. Press Ames., Iowa U. S. A.

Wang, C. Y. and W. M. Mellenthin (1973). Relationship of friction discoloration to phenolic compounds in d' Anjou pears. HortScience, 8 (4): 321 - 323.

Zeebroeck, M.V.; V. V. Linden; H. Ramon and J. De Baerdemaeker (2007). Impact damage of apples during transport and handling. Postharvest Biology and Technology. 45 (2): 157 - 167. 


\section{الملخص العربي}

\section{تأثيرميعاد الجمع على القابلية للاصابة بالكدمات، الجودة والقدرة التخزينية لثمار الحوخ صنف سويلنج}

$$
\text { نرمين اسماعيل النجار، رجاء موسي الصعيدى }
$$

تحول أسرع للون البني على درجة حرارة الغرفة. وخلال موسمي التجربة

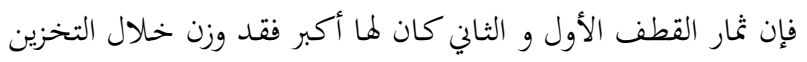

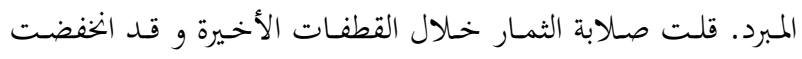
صلابة جميع الثمار التي درست خـالال التخزين المبرد. عند الجمع و

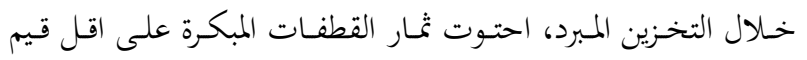

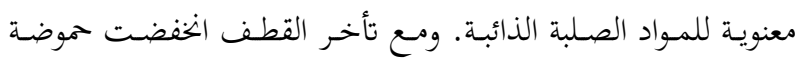

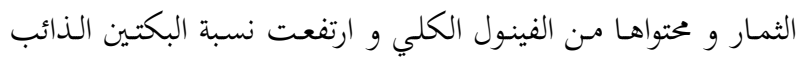
بها. يجب مراعاة أن قطف و تعبئة و نقل ثمار الخوخ يتم بعناية لتفادي الأصـابة بالكدمات مع مراعـاة تسويقها و استهلاكها خـلال ثـلاث

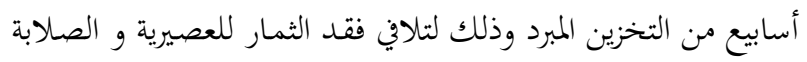
و ب التالي تقل جودة الثمار.

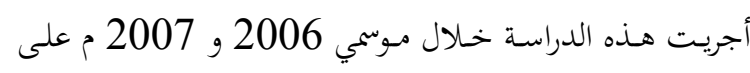

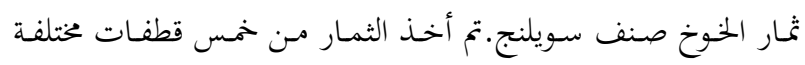

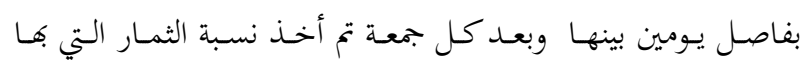

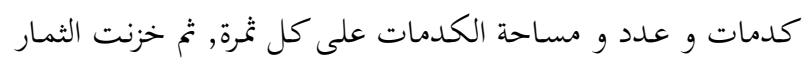

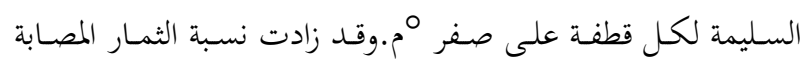

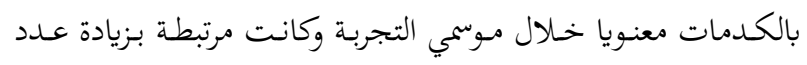

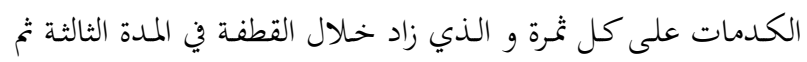

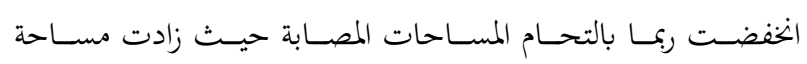

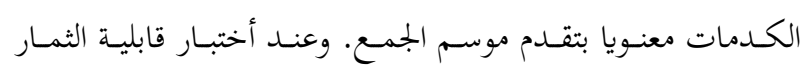

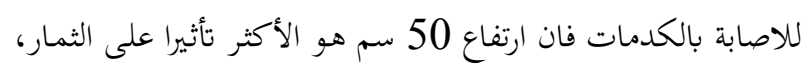

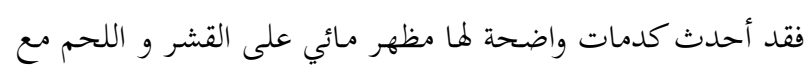

